Article

\title{
Religion and the Transmission of COVID-19 in The Netherlands
}

\author{
Paul Vermeer*(D) and Joris Kregting \\ Faculty of Philosophy, Theology and Religious Studies, Radboud University, P.O. Box 9103, \\ 6500 HD Nijmegen, The Netherlands; j.kregting@kaski.ru.nl \\ * Correspondence: p.vermeer@ftr.ru.nl
}

Received: 8 July 2020; Accepted: 28 July 2020; Published: 31 July 2020

\begin{abstract}
The aim of this study was to find out if the typical spread of hospitalized patients with COVID-19 in The Netherlands, with significantly higher levels in the Dutch Bible belt and the southern, traditionally Catholic provinces, is related to the specific religious composition of the country. To do this, government statistics regarding the level of hospitalized patients with COVID-19 per municipality were combined with statistics regarding church attendance and church membership rates. Results showed that in the Dutch Bible belt the level of patients with COVID-19 was strongly related to church attendance, but in the southern, traditionally Catholic part of The Netherlands nominal church membership mattered more than church attendance. On the basis of these findings, the conclusion was drawn that religion probably facilitates the spread of the virus in both a direct and indirect way. It facilitates the spread of the virus directly through worship services but also indirectly by way of endorsing more general cultural festivities like carnival and maybe even by strengthening certain non-religious social bonds. Epidemiologists monitoring the spread of the virus are called upon to focus more on these possible indirect or latent effects of religion.
\end{abstract}

Keywords: COVID-19; church attendance; church membership; The Netherlands

\section{Introduction}

After the outbreak of the COVID-19 virus in Wuhan, China, in December 2019, the virus spread over the globe and also came to Europe where it caused a first major outbreak in the North of Italy. Following the outbreak in Italy, the virus spread in various other European countries including The Netherlands. On 27 February 2020, the first contamination was reported in The Netherlands, and in the following weeks the number of contaminations and, subsequently, hospitalizations increased dramatically. In order to prevent the virus from spreading further and to reduce the pressure on the health care system, the Dutch government took drastic measures and announced a partial lockdown on March 15. From that day onwards Dutch public life virtually stopped as schools, museums, restaurants, bars, sports facilities, churches, and most shops closed their doors. This situation lasted until May 11. By that time the number of reported contaminations and the number of COVID-19 patients at IC-wards was again declining, and thus the government decided to lift some of the measures imposed. For instance, from that date, young children were allowed to attend primary school again.

However, between the report of the first contamination and the announcement of the first lift of the Corona measures on May 11, the virus did not spread evenly in The Netherlands. As indicated by the darkest spots in Figure 1, the highest levels of hospitalized patients per 100,000 inhabitants were found in municipalities primarily located in the southern part of The Netherlands as well as in small regional pockets in the south-west and the middle of The Netherlands. Other parts of The Netherlands were far less affected by COVID-19, and the upper north remained almost untouched. This is a remarkable observation. The Netherlands is a small and densely populated country with lots of interregional 
traffic. Therefore, one would expect the virus to spread fairly evenly across the country, but this did not happen. Instead, the virus seemingly spread along religious lines. For not only is the south traditionally Catholic and the north of The Netherlands traditionally Protestant, but most of the highly affected municipalities in the south-west and the middle of The Netherlands are located in highly religious areas known as the Dutch Bible belt. A pattern which suggests that the spread of COVID-19 could be linked to the way the Dutch are involved in church.

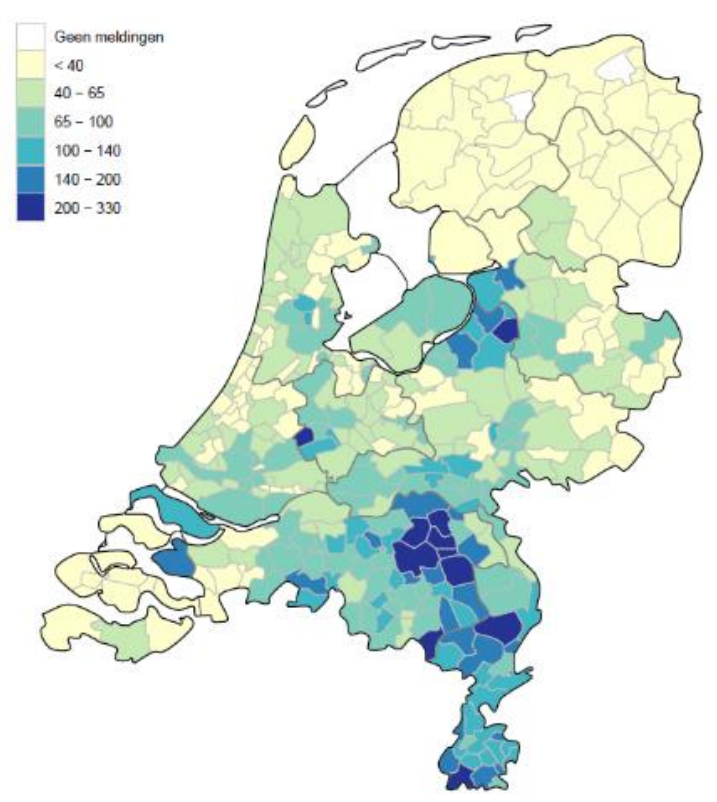

Figure 1. Hospitalized patients with COVID-19 per 100,000 inhabitants per municipality, 11 May 2020 (Dutch National Institute for Public Health and the Environment, RIVM).

To see if such a possible link between the spread of COVID-19 and church involvement in The Netherlands really exists is the main objective of this paper. To do this, we used high-quality data from the Dutch National Institute for Public Health and the Environment (RIVM) and from Statistics Netherlands (CBS) and addressed the following research question: To what extent is church involvement (church attendance and church membership) a factor in the spread of hospitalized patients with COVID-19 in The Netherlands? We focused on the number of hospitalized patients as an indicator for the spread of COVID-19 because the Dutch population as such is not tested and so the actual number of contaminations is unknown. In contrast, the actual number of hospitalized patients with COVID-19 is very well documented and thus is a reliable indicator of the spread of the virus.

\section{Theory and Hypotheses}

As mentioned already, there are two observations of the current pandemic which suggest a possible link between church involvement and the spread of COVID-19 in The Netherlands. Firstly, there is the difference in the levels of hospitalized patients between the north and the south which coincides with the traditional Protestant-Catholic divide in The Netherlands, and secondly, there are the relatively high levels of hospitalized patients in specific parts of the south-west and the middle of The Netherlands known as the Dutch Bible belt. These observations give rise to two hypotheses concerning church involvement and the spread of COVID-19 as we will explain more in detail below.

A major reason for assuming that religion plays a role in the transmission of COVID-19 is that religion is a communal activity. Of course, pivotal in religion are Gods and transcendent or superhuman powers, but these Gods or superhuman powers are also the objects of veneration and communication by way of culturally prescribed practices (Riesebrodt 2010; Smith 2017). Religion thus not only is a matter of belief but also a matter of culturally prescribed practices which are part of a tradition carried, 
endorsed, and transmitted by a community of people. For a religious tradition to survive, therefore, it is necessary that religious believers regularly come together, i.e., they have to congregate, in order to celebrate, endorse, and confirm their faith vis-à-vis one another. However, for people to participate in a communal activity like a worship service, it is very important that they are socially integrated with a religious community. This is a basic insight originating from Durkheim's social integration theory. As Durkheim (1983) pointed out in his famous study on suicide, people only abide by the rules and regulations of their faith to the extent that they are integrated with a local congregation. Although collective worship may be an important duty for every religious believer, only those believers who are socially integrated with a religious community will participate.

Collective worship thus is crucial to religion, and it is also the linking pin between religion and the spread of COVID-19. For when it comes to the spread of COVID-19, it is now widely recognized that dense gatherings play a crucial role. Dense gatherings can be large mass gatherings, such as the Hadj or the Brazilian carnival, but traveling on a cruise ship is also an example of a dense gathering. Crucial for the transmission of the virus is that people meet in congested places (Ebrahim and Memish 2020). Thus worship services can also be seen as dense gatherings and have indeed proven to be fertile ground for the transmission of COVID-19; as was the case, for instance, in South Korea where a specific Christian congregation turned out to be the source of a substantial number of COVID-19 infections among its attendees (Quadri 2020). Or in Germany where people got infected after visiting a worship service at a Baptist congregation ${ }^{1}$.

Religion thus facilitates the spread of COVID-19 by way of collective worship services as instances of dense gatherings. In this respect, the relatively high levels of hospitalized COVID-19 patients in parts of the Dutch Bible belt may come as no surprise. In these areas, more orthodox Protestant denominations and Pentecostal and evangelical congregations, whose members very frequently attend church, dominate the religious scene. These churches mostly constitute close-knit and well-integrated religious communities in which frequent church attendance continues to be an important social norm (De Hart 2014; Vermeer and Scheepers 2017, 2018)2.

However, similar to other West-European countries (Davie 2000), The Netherlands is also characterized by a relatively high proportion of nominal church members. That is to say, a significant number of the Dutch who indicate to be affiliated to a Christian denomination are not very well integrated with a local religious community and hardly or never participate in collective worship. A phenomenon which is especially typical for Dutch Catholics-the largest denomination in The Netherlands-as their church attendance rates clearly show. According to Statistics Netherlands (Schmeets 2016), in 2015, only 17 per cent of Dutch Catholics attended church on a regular basis, i.e., at least once a month. For comparison, among Orthodox Protestants in the Dutch Bible belt approximately 78 per cent regularly attend church (Bernts and Berghuijs 2016). Consequently, in large parts of the southern, traditionally Catholic and highly affected areas in The Netherlands it is quite unlikely that church attendance or nominal church membership has contributed much to the spread of COVID-19; despite the apparent coincidence between the spread of the virus and the traditional Protestant-Catholic divide in the country.

These considerations concerning the religious situation in The Netherlands show, we believe, that the relationship between church involvement and the spread of COVID-19 may be more subtle than Figure 1 seems to suggest at first glance. As a result, we formulate and, subsequently, test two hypotheses. Since church attendance, as an instance of participating in a dense gathering, matters more for the spread of the virus than mere or nominal church membership, our first hypothesis reads:

1 See: https://www.tagesspiegel.de/politik/sehr-dynamisches-geschehen-mehr-als-40-menschen-infizieren-sich-bei-gotte sdienstbesuch-in-frankfurt-am-main/25854262.html.

2 The spread of COVID-19 in parts of the Dutch Bible belt also caught the attention of Dutch media. See for instance: https: //www.trouw.nl/religie-filosofie/het-coronavirus-verspreidt-zich-razendsnel-op-een-deel-van-de-biblebelt \{\}b7dc7d01/. 
Hypothese 1. Overall, there will be a stronger relationship between church attendance and the level of hospitalized patients with COVID-19 than between nominal church membership and the level of hospitalized patients with COVID-19.

Secondly, given the high levels of church involvement and socio-religious integration in the Dutch Bible belt, we expect to find a strong relationship between church attendance and COVID-19 in this part of the country. However, given the relatively high level of nominal church membership among Catholics, we do not think that the peak of COVID-19 in the south is related to church attendance. Therefore, our second hypothesis reads:

Hypothese 2. There will be a strong relationship between church attendance and the level of hospitalized patients with COVID-19 in the non-southern part of The Netherlands, but there will be no or only a very weak relationship between church attendance and the level of hospitalized patients with COVID-19 in the southern, traditionally Catholic part of The Netherlands.

To test these hypotheses we took municipalities as our unit of analysis and looked for associations between the relative number of church members and regular attendees and the relative number of hospitalized patients with COVID-19 per municipality. Furthermore, to check if possible associations between church attendance and COVID-19 hospitalizations were not spurious, we controlled in our analyses for age, health, and intensive livestock farming ${ }^{3}$. To control for age is important for two reasons. First of all, people aged 65 and over generally are more involved in church (De Hart 2014) and, secondly, people ages 70 and over are also overrepresented among the hospitalized patients with COVID-19 in The Netherlands. Regarding health, we controlled for the proportion of overweight citizens because people with obesity have a higher risk of becoming ill, and thus of becoming hospitalized, if they are infected by the virus (Stefan et al. 2020). In addition, we also controlled for the intensity of livestock farming because people living in the vicinity of livestock farms more often have respiratory problems which also puts them in a risk group for the virus (Borlée et al. 2017) ${ }^{4}$.

\section{Method}

\subsection{Data}

In The Netherlands, the National Institute for Public Health and the Environment (RIVM), which is part of the Ministry of Health, Welfare, and Sport, is the main supplier of statistics regarding COVID-19, as well as for government policy. On a daily basis and in cooperation with the Municipal Public Health Services (GGDs), this institute provided data at the level of municipalities regarding the three main COVID-19 parameters: positively tested persons, persons admitted to the hospital ("hospitalized patients"), and reported deaths. Statistics Netherlands (CBS) provided the social-cultural data at the level of municipalities for the factors we used to explain the regional differences in the spread of COVID-19 as suggested in the previous section; i.e., church involvement (church attendance and church membership), age, health, and intensive livestock farming. The specific variables we used are described in more detail below ${ }^{5}$.

3 We did not control for gender because in all municipalities in The Netherlands men and women are distributed almost equally.

4 Information regarding the number of hospitalized patients with COVID-19, deaths and various age and risk groups can be found on the website of the Dutch National Institute for Public Health and the Environment (RIVM), see https: //www.rivm.nl/en, as well as in the epidemiological report which is updated daily: https://www.rivm.nl/documenten/dagelij kse-update-epidemiologische-situatie-covid-19-in-nederland.

5 All non-COVID-19 data are available at Statline of Statistics Netherlands: https://opendata.cbs.nl/statline/\#/CBS/nl/navigati eScherm/thema?themaNr=4440. 


\subsection{Dependent Variable}

In our analyses, the spread of COVID-19 was expressed by the total number of hospitalized patients with COVID-19 per 100,000 residents of each Dutch municipality in the period between March 3 up to 11 May 2020. The range of this dependent variable corresponds with the map displayed in the introduction. The number of hospitalized patients differs significantly among municipalities with some municipalities in the north harboring no or almost no patients and several municipalities in the south harboring more than 300 patients per 100,000 inhabitants. At the beginning of 2020, The Netherlands comprised 355 municipalities. As a test of robustness, we also performed our analyses with the number of reported deaths as an alternative for hospitalized patients. Results of this test are presented in Appendix A (Table A2).

\subsection{Independent Variables}

Our main theoretical concept for explaining the regional spread of COVID-19 in The Netherlands concerned church involvement for which we had two indicators: church attendance and church membership. Church attendance concerned the proportion of the population per municipality (over 18 years of age) that attended worship services on a regular base, i.e., at least once a month. However, most of these churchgoers were, of course, also church members. Therefore, to distinguish more clearly between church attendance and church membership and to avoid multicollinearity in our analyses, we operationalized church membership as nominal church membership. This is the proportion of church members of the population per municipality (over 18 years of age) that attended worship services less than once a month ${ }^{6}$. The data we used were collected as part of the Dutch survey for the labor force, performed by Statistics Netherlands in the period 2010 to 2015 with over 600,000 respondents. Municipalities with less than 150 respondents were left out of consideration ( 5 of 355 municipalities).

\subsection{Control Variables}

As mentioned above, we controlled for age, a specific health factor, and intensive livestock farming. Age concerned the proportion of the population per municipality aged 70 and over. These were registration data (1 January 2019) gathered by Statistics Netherlands with no missing values $(n=355)$. The health factor concerned the proportion of overweight citizens per municipality in the population of over 19 years of age. These data came from the national representative survey "Health monitor 2016" conducted by Statistics Netherlands. Data of two municipalities were missing $(n=353)$. Intensive livestock farming concerned the number of all pigs, poultry, rabbits, and fur-bearing animals per citizen per municipality. These were registration data (1 January 2019) gathered by Statistics Netherlands with no missing values $(\mathrm{n}=355)$.

Our analyses included 350 municipalities with data for all dependent and independent variables. The descriptive statistics of the variables are presented in Table A1 in Appendix A.

\subsection{Analytical Strategy}

In order to test the aforementioned hypotheses and to answer our research question, we proceeded as follows. First, we considered the bivariate associations between church involvement,

6 Since we focused on areas with higher levels of hospitalized patients with COVID-19 that were predominantly Christian, Muslims were excluded in the data on church attendance and church membership. Statistic Netherlands only registers the percentage of Muslims in each municipality and not the frequency of mosque attendance. Based on earlier research into the religious practices of Dutch Muslims we estimated that 45 per cent of these Muslims attended mosque on a regular base, i.e., at least once a month (Huijnk 2018), and 55 per cent were "nominal Muslims." Thus the percentage of regular church attendance per municipality included all churchgoers minus 45 per cent of the percentage of Muslims in each municipality, and the percentage of nominal church members included all church members minus the regular churchgoers and minus 55 per cent of the percentage of Muslims in each municipality. 
i.e., church attendance and nominal church membership, and the spread of hospitalized patients with COVID-19 and tested Hypothesis 1. As a next step, we tested Hypothesis 2 by conducting three linear regression analyses in which we respectively considered the effect of church attendance on the spread of hospitalized patients with COVID-19 for The Netherlands as a whole, for the non-southern parts of The Netherlands, including the Dutch Bible belt, and for the southern, traditionally Catholic part of The Netherlands ${ }^{7}$. In these regression analyses, we also included nominal church membership as an additional control variable.

\section{Results}

Table 1 displays the correlations between all variables included in our study for The Netherlands as a whole, for the non-southern parts of The Netherlands, and for the traditionally Catholic south. One remarkable finding immediately caught the eye; viz. in The Netherlands as a whole as well as in the south of The Netherlands nominal church membership was significantly and strongly related to the level of hospitalized patients per municipality, while the association between regular church attendance and the level of hospitalized patients with COVID-19 was non-significant. This result was not in line with our first hypothesis (H1). Only in the non-southern parts of The Netherlands did we find support for our hypothesis. That is to say, only in these areas, which also comprise the Dutch Bible belt, did we indeed find a significant relationship between church attendance and the level of hospitalized patients per municipality, while the relationship between nominal church membership and the level of hospitalized patients was non-significant. Furthermore, not only was nominal church membership most strongly related to the level of hospitalized patients in The Netherlands as a whole and in the south of The Netherlands, but in these areas nominal church membership was also more strongly related to the level of hospitalized patients than any other factor. In part, this also goes for the non-southern parts of The Netherlands; i.e., in these areas regular church attendance was more strongly related to the level of hospitalized patients than any other factor. These findings clearly suggest that there is indeed a close link between church involvement, be it regular church attendance or nominal church membership, and the spread of hospitalized patients with COVID-19 in The Netherlands.

But does this effect of regular church attendance, and of nominal church membership, persist when we control for the possible influence of other relevant factors in a multivariate analysis? Table 2, which presents the results of three regression analyses, provides an answer to this question. Again, these results show that church involvement is indeed a very important predictor of the level of hospitalized patients per municipality. Even when we controlled for other factors, a considerable effect of church involvement remained in all three analyses ${ }^{8}$.

Regarding The Netherlands as a whole, church attendance was indeed an important predictor of the level of hospitalized patients per municipality, but nominal church membership turned out to be even more important. Furthermore, there was also a significant but weaker effect of intensive livestock farming. Together, all factors explained 33.2 per cent of the variance in the level of hospitalized patients with COVID-19, which was considerable. These findings thus again rejected our first hypothesis. Contrary to our expectation, nominal church membership was a more important predictor of the level of hospitalized patients per municipality than regular church attendance. The different $b$-values clearly illustrate this. These values indicate that if the proportion of regular churchgoers increases by 1 per cent, the level of hospitalized patients per 100,000 inhabitants will increase by 0.60 per cent, but if the proportion of nominal church members increases by 1 per cent, the level of hospitalized patients per 100,000 inhabitants will increase by 2.05 per cent.

7 The South-western province Zeeland is classified under the non-southern parts of The Netherlands because hardly any Catholics are living in this part of The Netherlands.

8 As mentioned already, we performed a test of robustness by taking the number of reported deaths as an alternative dependent variable. This did not change our results. The same variables remained significant, only the effects were weaker (cf. Table A2 in Appendix A). 
Table 1. Correlations (Pearson's r).

\begin{tabular}{|c|c|c|c|c|c|c|c|c|c|c|c|c|c|c|c|}
\hline & \multicolumn{3}{|c|}{$\begin{array}{c}\text { Proportion Church } \\
\text { Attendance on a Regular } \\
\text { Base }\end{array}$} & \multicolumn{3}{|c|}{$\begin{array}{c}\text { Proportion Nominal Church } \\
\text { Members }\end{array}$} & \multicolumn{3}{|c|}{$\begin{array}{c}\text { Proportion Citizens over } 70 \\
\text { Years of Age }\end{array}$} & \multicolumn{3}{|c|}{$\begin{array}{c}\text { Proportion of Overweight } \\
\text { Citizens }\end{array}$} & \multicolumn{3}{|c|}{ Intensive Livestock Farming } \\
\hline & NL & $\begin{array}{l}\text { Non- } \\
\text { South. } \\
\text { NL }\end{array}$ & $\begin{array}{l}\text { South. } \\
\text { NL }\end{array}$ & NL & $\begin{array}{l}\text { Non- } \\
\text { South. } \\
\text { NL }\end{array}$ & $\begin{array}{l}\text { South. } \\
\text { NL }\end{array}$ & NL & $\begin{array}{l}\text { Non- } \\
\text { South. } \\
\text { NL }\end{array}$ & $\begin{array}{l}\text { South. } \\
\text { NL }\end{array}$ & NL & $\begin{array}{l}\text { Non- } \\
\text { South. } \\
\text { NL }\end{array}$ & South. NL & NL & $\begin{array}{c}\text { Non- } \\
\text { South. NL }\end{array}$ & South. NL \\
\hline Hospitalized patients per 100,000 residents & -0.004 & $0.194 * *$ & 0.140 & $0.534 * *$ & 0.094 & $0.407^{* *}$ & 0.013 & $-0.152 *$ & -0.045 & -0.020 & 0.008 & $-0.208^{*}$ & 0.294 ** & -0.036 & $0.279 * *$ \\
\hline Proportion church attend. regular basis & & & & $-0.284^{* *}$ & $-0.205 * *$ & 0.021 & $-0.214^{* *}$ & -0.238 ** & $0.337^{* *}$ & 0.053 & 0.064 & 0.119 & $0.147^{* *}$ & $0.397^{* *}$ & 0.102 \\
\hline Proportion nominal church members & & & & 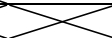 & $>$ & $\sum_{r_{1}}$ & $0.235^{* *}$ & $0.128^{*}$ & $0.308^{* *}$ & $0.105^{*}$ & 0.062 & $0.262 *$ & $0.311^{* *}$ & 0.037 & $0.339 * *$ \\
\hline Proportion citizens over 70 years of age & & & & & & & $\sum<$ & 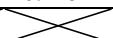 & & 0.148 ** & $0.142 * *$ & 0.132 & -0.020 & -0.034 & -0.178 \\
\hline Proportion of overweight citizens & & & & & & & & & & & & 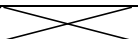 & 0.033 & $0.193 *$ & $-0.213^{*}$ \\
\hline Intensive livestock farming & & & & $\varnothing$ & $\varnothing$ & $\infty$ & $\sum$ & $\sum$ & $\sum$ & $\sum$ & $\sum$ & $\sum$ & $\mathrm{S}_{\mathrm{S}}$ & $\mathrm{S}_{\mathrm{S}}$ & $\mathrm{Sr}$ \\
\hline
\end{tabular}

*** $p<0.001 ; * * p<0.01 ; * p<0.05$. 
Table 2. Linear regression analyses (B's) of hospitalized patients with COVID-19 per 100,000 residents (March 2-May 11).

\begin{tabular}{cccc}
\hline & The Netherlands & $\begin{array}{c}\text { Non-Southern Parts of } \\
\text { The Netherlands }\end{array}$ & $\begin{array}{c}\text { Southern Part of } \\
\text { The Netherlands }\end{array}$ \\
\hline Constant & 53.816 & 36.979 & 262.740 \\
Proportion church attendance on a regular basis & $0.604^{* *}$ & $0.701^{* * *}$ & $3.603 * *$ \\
Proportion nominal church members & $2.052^{* * *}$ & $0.593 * *$ & $5.620 * * *$ \\
Proportion citizens over 70 years of age & -170.798 & -158.023 & $-1040.739 * *$ \\
Proportion of overweight citizens & -0.920 & 0.203 & $-6.662^{* * *}$ \\
Intensive livestock farming & $0.222^{*}$ & $-0.368^{*}$ & -0.099 \\
$R^{2}$ & 0.332 & 0.091 & 0.362 \\
Number of municipalities & 350 & 257 & 93 \\
\hline
\end{tabular}

${ }^{* * *} p<0.001 ;{ }^{* *} p<0.01 ;{ }^{*} p<0.05$.

While nominal church membership was a more important factor for the level of hospitalized patients with COVID-19 when we considered The Netherlands as a whole, things were different when we concentrated on the non-southern parts of The Netherlands. In these parts, which also include the Dutch Bible belt, regular church attendance was indeed the most important factor for explaining the level of hospitalized patients. However, in these parts of The Netherlands, church involvement together with intensive livestock farming and all other factors in the equation only explained 9.1 per cent of the variance in the level of hospitalized patients. Overall, these findings were in line with our second hypothesis (H2). In these non-southern parts of The Netherlands, church attendance matters more than nominal church membership and appears to be the most important predictor for the level of hospitalized patients per municipality.

When we concentrated on the southern, traditionally Catholic part of The Netherlands, this second hypothesis (H2) was again rejected by our findings. Contrary to our expectations, we also found a very strong positive effect of regular church attendance on the level of hospitalizations in this part of The Netherlands; next to an even stronger positive effect of nominal church membership. In addition, our analysis also revealed negative effects on the proportion of overweight citizens and the proportion of citizens aged 70 and over. That is to say, to the extent municipalities in the south harbor a larger proportion of overweight citizens or citizens aged 70 and over, their level of hospitalized patients will be lower. Together, all factors explained 36.2 per cent of the variance in the level of hospitalized patients, which was again considerable ${ }^{9}$.

In view of our hypotheses, our analyses thus revealed some unexpected findings. Our results clearly showed that there is indeed a link between church involvement, i.e., both church attendance and nominal church membership, and the spread of hospitalized patients with COVID-19 in The Netherlands. However, this link is somewhat different than we expected. Hypothesis 1, which states that the level of hospitalized patients with COVID-19 will be more strongly related to church attendance than to nominal church membership, was only confirmed for the non-southern parts of The Netherlands. Only in these parts of the country is church attendance a more important predictor of the spread of hospitalized patients than nominal church membership. As a consequence, Hypothesis 2 was also only partially confirmed by our findings. In the non-southern parts of The Netherlands there was indeed a significant relationship between church attendance and the spread of hospitalized patients

9 The effect of church involvement on the level of hospitalized patients with COVID-19 is far stronger in the southern, traditionally Catholic part of The Netherlands than in the other non-southern parts of The Netherlands. In this latter part of the country an increase of 1 per cent in the proportion of regular churchgoers results in an increase of 0.70 per cent in the level of hospitalized patients, and an increase of 1 per cent in the proportion of nominal church members results in an increase of 0.59 per cent in the level of hospitalized patients. However, when it comes to the Catholic south, an increase of 1 per cent in the proportion of regular churchgoers results in an increase of 3.60 per cent in the level of hospitalized patients, and an increase of 1 per cent in the proportion of nominal church members results in an increase of 5.62 per cent in the level of hospitalized patients. 
with COVID-19, but, contrary to our expectations, in the southern, traditionally Catholic parts of the country this relationship was even stronger.

\section{Discussion}

Triggered by the specific pattern of the regional spread of hospitalized patients with COVID-19 in The Netherlands, we addressed the following research question: To what extent is church involvement (church attendance and church membership) a factor in the spread of hospitalized patients with COVID-19 in The Netherlands? A research question we may now answer as follows: there is a strong link between nominal church membership and to a lesser extent church attendance and the spread of hospitalized patients with COVID-19 in the southern, traditionally Catholic part of The Netherlands and a weaker link between church attendance and nominal church membership and the spread of hospitalized patients with COVID-19 in the non-southern parts of The Netherlands. What does this mean?

This answer implies, we believe, that collective worship is not the only linking pin between religion and the spread of hospitalized patients with COVID-19. In the non-southern parts of The Netherlands, the effect of regular church attendance on the level of hospitalized patients is stronger than the effect of nominal church membership. With respect to these areas, which also comprise the Dutch Bible belt, it is probably justified to say, therefore, that attending worship services has been an important cause for the spread of the virus; although the relatively low explained variance suggests that other relevant factors besides church involvement had to also be at work here. But for the southern, traditionally Catholic part of The Netherlands, the idea that the virus primarily spread because people participated in worship services does not hold. That is not to say that worship services have nothing to do with the spread of the virus in this part of the country. In addition, in the southern, traditionally Catholic parts of The Netherlands, there is still a relatively strong effect of regular church attendance on the level of hospitalized patients with COVID-19, but this effect is much weaker than the effect of nominal church membership. This indicates, we believe, that religion may also facilitate the spread of the virus in other ways than bringing people together in a dense gathering like a worship service. In this respect, we see two additional ways in which religion could also contribute to the spread of the virus.

First, religious traditions may have a deep and lasting impact on the value systems and cultural practices of a nation even if large segments of the population are no longer religious. Thus it is sometimes assumed, for instance, that the values and norms in traditionally Catholic and traditionally Protestant areas still differ significantly even if the people living in these areas hardly or never attend church (Norris and Inglehart 2004). Something similar might be the case, we believe, with regard to the cultural practice of carnival. During the 1960s, the carnival became very popular in the southern and traditionally Catholic Dutch provinces of Brabant and Limburg and was eventually also endorsed by the Catholic clergy. For example, in this period the phenomenon of the "carnavalsmis" was introduced, i.e., the opening of the carnival with a special Catholic mass, which is still practiced today. From this period onwards, then, there has been a strong association between the carnival and Catholicism, and many Dutch nowadays consider the carnival as typically Catholic (Pleij 1992). Today, the carnival is a mass gathering and is immensely popular in the aforementioned southern provinces and thus also attracts a substantial number of (nominal) Catholics. Moreover, this mass gathering took place only a week before the first outbreak of the virus in the south of The Netherlands (February 22-25). During the carnival, lots of people in the south drink, sing, and dance together in small pubs, which thus creates ideal circumstances for the spread of the virus. Furthermore, if the link between nominal, Catholic church membership and the level of hospitalized patients with COVID-19 actually boils down to a link between the carnival and the spread of COVID-19, as we suggest, the negative effects we found of the proportion of citizens aged 70 and over and overweight citizens could be explained as well (cf. Table 2). For it could very well be the case that these latter groups celebrate the carnival differently or less intensely. Maybe older people or overweight people are less involved in the drinking, singing, 
and dancing in small pubs during the carnival than younger people or people who do not suffer from obesity and thus they face a lower risk of getting contaminated by the virus during the carnival.

However, given the strong effect of nominal church membership and to a lesser extent church attendance in the south of The Netherlands, it is unlikely that we are only dealing with a "carnival-effect" here. This brings us to a second way in which religion could indirectly facilitate the spread of the virus. In The Netherlands as well as in other countries, religion is still an important source of social capital; i.e., churchgoers are more likely than secular people to donate money to charity or to participate in all kinds of voluntary associations (Ruiter and Graaf 2006). Moreover, when it comes to volunteering, there is also a difference between Orthodox Protestants, Pentecostals, and Evangelicals on the one hand and mainline Protestants and Catholics on the other. Mainline Protestants and Catholics not only primarily volunteer for religious organizations, e.g., their own religious community, but they are also actively involved in secular organizations (Musick and Wilson 2008; Vermeer and Scheepers 2019). Mainline Protestants and Catholics in this respect display a stronger, so-called spillover effect. That is to say, their volunteering for a religious organization spills over to a secular organization. In addition, regarding The Netherlands, there is also evidence that this spillover effect is stronger among Catholics than among mainline Protestants (Bekkers and Schuyt 2008), while there is also additional evidence that people who were raised as Catholic but stopped attending church continue to display higher levels of civic involvement (Vermeer and Scheepers 2012). Consequently, it is very well possible that compared to secular people and non-church members, mainline Christians and especially (nominal) Catholics in the south are more involved in dense social networks. As a result, these mainline Christians may have a higher risk of becoming infected by COVID-19 and of spreading the virus themselves. Seen from this perspective, then, the strong link between nominal church membership and to a lesser extent church attendance we witness in the south may also be the result of more dense, non-religious social relationships that are fostered by people's religious (Catholic) background and identity.

\section{Conclusions}

All over the world governments took drastic measures in order to prevent the virus from spreading further. One of these measures was the closing of churches and the prohibition of religious services. In light of the right of the free exercise of religion, such a ban on church services may be considered controversial. Still, given the strong link between church attendance and the spread of the virus, one cannot but conclude that such a ban is justified in order to safeguard public health. As we showed in this paper, even in such a secular country like The Netherlands, there is still a strong relationship between church attendance and the level of hospitalized patients with COVID-19. However, as we also suspect, in secular Dutch society, religion probably not only affects the level of hospitalized patients with COVID-19 in a direct way. By endorsing certain cultural festivities and by strengthening certain non-religious, social bonds, religion could also facilitate the spread of the virus in a more indirect way. For epidemiologists monitoring the spread of the virus, it is very important, therefore, to focus not only on manifest religious gatherings but to also be aware of the more latent effects a given religious culture could have on the behavior of individuals and groups.

Author Contributions: Conceptualization, P.V.; methodology, P.V. and J.K.; formal analysis, J.K.; data curation, J.K.; writing - original draft preparation, P.V. and J.K.; writing-review and editing, P.V. All authors have read and agreed to the published version of the manuscript.

Funding: This research received no external funding.

Conflicts of Interest: The authors declare no conflict of interest. 


\section{Appendix A}

Table A1. Descriptive statistics.

\begin{tabular}{|c|c|c|c|c|c|c|c|c|c|c|c|c|c|c|c|}
\hline & \multicolumn{3}{|c|}{$\mathbf{N}$} & \multicolumn{3}{|c|}{ Minimum } & \multicolumn{3}{|c|}{ Maximum } & \multicolumn{3}{|c|}{ Mean } & \multicolumn{3}{|c|}{ Std. Deviation } \\
\hline & NL & $\begin{array}{l}\text { Non-Southern } \\
\text { NL }\end{array}$ & $\begin{array}{l}\text { Southern } \\
\text { NL }\end{array}$ & NL & $\begin{array}{l}\text { Non-Southern } \\
\text { NL }\end{array}$ & $\begin{array}{l}\text { Southern } \\
\text { NL }\end{array}$ & NL & $\begin{array}{l}\text { Non-Southern } \\
\text { NL }\end{array}$ & $\begin{array}{l}\text { Southern } \\
\mathrm{NL}\end{array}$ & NL & $\begin{array}{l}\text { Non-Southern } \\
\text { NL }\end{array}$ & $\begin{array}{l}\text { Southern } \\
\text { NL }\end{array}$ & NL & $\begin{array}{c}\text { Non-Southern } \\
\text { NL }\end{array}$ & $\begin{array}{c}\text { Southern } \\
\text { NL }\end{array}$ \\
\hline Hospitalized patients per 100,000 residents & 350 & 257 & 93 & 0.00 & 0.00 & 22.75 & 327.78 & 263.72 & 327.78 & 70.07 & 51.79 & 120.59 & 54.59 & 34.84 & 66.28 \\
\hline Proportion church attendance on a regular basis & 350 & 257 & 93 & 2.59 & 2.59 & 6.64 & 93.63 & 93.63 & 36.53 & 17.44 & 19.01 & 13.11 & 11.67 & 12.91 & 5.22 \\
\hline Proportion nominal church members & 350 & 257 & 93 & 4.16 & 4.16 & 33.94 & 72.49 & 61.04 & 72.49 & 37.82 & 30.71 & 57.46 & 14.87 & 9.63 & 7.027 \\
\hline Proportion citizens over 70 years of age & 350 & 257 & 93 & 0.06 & 0.06 & 0.12 & 0.24 & 0.24 & 0.21 & 0.15 & 0.15 & 0.16 & 0.03 & 0.03 & 0.02 \\
\hline Proportion of overweight citizens & 350 & 257 & 93 & 35.50 & 35.50 & 41.20 & 64.20 & 64.20 & 59.80 & 50.26 & 50.10 & 50.70 & 4.61 & 4.84 & 3.86 \\
\hline Intensive livestock farming & 350 & 257 & 93 & 0.00 & 0.00 & 0.00 & 211.77 & 123.21 & 211,77 & 12.19 & 789 & 24.07 & 24.43 & 14.68 & 38.34 \\
\hline
\end{tabular}


Table A2. Linear regression analyses (B's) of reported deaths due to COVID-19 per 100,000 residents (March 2-May 11).

\begin{tabular}{|c|c|c|c|}
\hline & The Netherlands & $\begin{array}{l}\text { Non-Southern Parts of } \\
\text { The Netherlands }\end{array}$ & $\begin{array}{l}\text { Southern Part of } \\
\text { The Netherlands }\end{array}$ \\
\hline Constant & 49.319 & 31.971 & 243.608 \\
\hline Proportion church attendance on a regular basis & $0.290 *$ & 0.306 ** & $1.900 *$ \\
\hline Proportion nominal church members & $1.005^{* * *}$ & 0.216 & $2.695^{* * *}$ \\
\hline Proportion citizens over 70 years of age & -61.167 & -35.561 & $-657.744 * *$ \\
\hline Proportion of overweight citizens & $-0.992 * *$ & -0.295 & $-4.982 * * *$ \\
\hline Intensive livestock farming & $0.068 *$ & -0.085 & $-0.234 *$ \\
\hline$R^{2}$ & 0.248 & 0.043 & 0.302 \\
\hline Number of municipalities & 350 & 257 & 93 \\
\hline
\end{tabular}

\section{References}

Bekkers, Rene, and Theo Schuyt. 2008. And who is your neighbour? Explaining denominational differences in charitable giving and volunteering in The Netherlands. Review of Religious Research 62: 315-35.

Bernts, Ton, and Joantine Berghuijs. 2016. God in Nederland 1966-2015. Utrecht: Ten Have.

Borlée, Floor, Joris C. Yzermans, Bernadette Aalders, Jos Rooijackers, Esmeralda Krop, Catharina B. M. Maassen, Francois Schellevis, Bert Brunekreef, Dick Heederik, and Lidwien A. M. Smit. 2017. Air pollution from livestock farms is associated with airway obstruction in neighboring residents. American Journal of Respiratory and Critical Care Medicine 169: 1152-61. [CrossRef] [PubMed]

Davie, Grave. 2000. Religion in Modern Europe. A Memory Mutates. Oxford: Oxford University Press.

De Hart, Joep. 2014. Geloven binnen en buiten verband. Godsdienstige ontwikkelingen in Nederland. Den Haag: SCP. Durkheim, Emile. 1983. Der Selbsmord. Frankfurt am Main: Suhrkamp.

Ebrahim, Shahul H., and Ziad A. Memish. 2020. COVID-19-The role of mass gatherings. Travel Medicine and Infectious Disease 34. [CrossRef]

Huijnk, Willem. 2018. De Religieuze Beleving Van Moslims in Nederland. Diversiteit en Verandering in Beeld. Den Haag: SCP.

Musick, Mark A., and John Wilson. 2008. Volunteers. A Social Profile. Bloomington: Indiana University Press.

Norris, Pippa, and Ronald Inglehart. 2004. Sacred and Secular. Religion and Politics Worldwide. Cambridge: University Press.

Pleij, Herman. 1992. Van Vastelavond tot Carnaval. In Vastenavond-Carnaval. Feesten Van De Omgekeerde Wereld. Edited by Charles de Mooij. Zwolle: Waanders, pp. 10-44.

Quadri, Sayed A. 2020. COVID-19 and religious congregations: Implications for spread of novel pathogens. International Journal of Infectious Diseases 96: 219-21. [CrossRef] [PubMed]

Riesebrodt, Martin. 2010. The Promise of Salvation. A Theory of Religion. Chicago: The University of Chicago Press. Ruiter, Stijn, and Nan Dirk De Graaf. 2006. National context, religiosity, and volunteering. Results from 53 countries. American Sociological Review 71: 191-210. [CrossRef]

Schmeets, Hans. 2016. De Religieuze Kaart Van Nederland, 2010-2015. Den Haag/Heerlen: CBS.

Smith, Christian. 2017. Religion. What It Is, How It Works, and Why It Matters. Princeton: Princeton University Press.

Stefan, Norbert, Andreas L. Birkenfeld, Matthias B. Schulze, and David S. Ludwig. 2020. Obesity and impaired metabolic health in patients with COVID-19. Nature Reviews Endocrinology 16: 341-42. [CrossRef]

Vermeer, Paul, and Peer Scheepers. 2012. Religious socialization and non-religious volunteering. A panel study. Voluntas 23: 940-58. [CrossRef]

Vermeer, Paul, and Peer Scheepers. 2017. Umbrellas of conservative belief. Explaining the success of evangelical congregations in The Netherlands. Journal of Empirical Theology 30: 1-24. [CrossRef]

Vermeer, Paul, and Peer Scheepers. 2018. Committed believers: Determinants of the organizational commitment of Dutch evangelicals. Journal of Religion in Europe 11: 291-326. [CrossRef]

Vermeer, Paul, and Peer Scheepers. 2019. Bonding or bridging? Volunteering among the members of six thriving evangelical congregations in The Netherlands. Voluntas 30: 962-75. [CrossRef]

(C) 2020 by the authors. Licensee MDPI, Basel, Switzerland. This article is an open access article distributed under the terms and conditions of the Creative Commons Attribution (CC BY) license (http://creativecommons.org/licenses/by/4.0/). 